addition reactions have chapters to themselves, and logically there is a chapter on the determination of molecular weights of polymers. Much is necessarily compressed into this chapter, and the intending experimentalist would need to refer to the original works for more detailed instructions on the use of the more complicated methods. Methods of following polymerization and a detailed discussion of the kinetics of free radical and to a lesser extent of carbonium ion reactions receive their proper place in the volume. The final chapter dcals in considerable detail with the phenomenon of emulsion polymerization, which is, of course, of very considerable technical importance.

As will be seen from the abovo remarks, the order of presentation is in a way scientifically illogical; but for those who are interested in the more applied side of polymer chemistry the arrangement is more likely to be acceptable. Polymerization is an open field for nomenclature enthusiasts, and the author brings forward a number of definitions throughout the book. About the time of publication the High Polymer Commission of the International Union of Pure and Applied Chemistry published a recommended system as a result of prolonged discussion, and it is perhaps a little unfortunate that it was not possible for the author to see this document and adopt some of the suggestions. The book was completed in May 1952; but in some of the discussions, particularly on the mechanism of polymerization, the treatment is not quite so up to date as would be expected from the date on the preface. The volume is well printed and bound. Its price is on the high side for purchasers on the eastern side of the Atlantic.

H. W. Menville

\section{BIRDS OF BURMA}

\section{The Birds of Burma}

By Bertram E. Smythies. Second. (revised) edition. Pp. xliii $+668+31$ plates. (Edinburgh and London: ()liver and Boyd, Ltd., 1953.) 84s. net.

GEVENTY years ago, E. W. Oates published his $D$ "Birds of Burma,", but the Burma of those days was restricted to that part of the country from Arakan and Pegu southwards. Shortly after the beginning of the present century the whole of Burma came under British rule, and the army officers, civilian officials and others took a great interest in birds. A new book has for a long time been needed, but it was not until a few years before the Second World War that Mr. H. C. Smith, a senior forest officer, planned the present work-or rather tho original edition. Mr. J. K. Stanford undertook to prepare the letterpress, and the services of Commander A. M. Hughes, who was at that time stationed in Rangoon, were secured to draw the plates. Then the War came; Hughes and Stanford were recalled home, and though the plates were completed the manuscript was not ready. The present author, Mr. B. E. Smythies, came to the rescue, and by the year 1941 the book was published.

Owing to the War, fow copies found their way out of the country, and before the end of the year the book was out of print. Shortly before orders were issued to evacuate Rangoon, Smythies rescued twenty-one of the thirty blocks for the plates and sent them to Calcutta. The original plates were saved by Mrs. Smith, but only through her sacrificing some of her personal belongings so as to keep within the 30 -lb. allowance to ovacuees flown out of Rangoon. When the Japanese arrived, they collected all the copies of the book they could find in Rangoon and elsewhere and sent them to Tokyo, only to be destroyed later whon the building in which they were housed was struck by a bomb.

The new edition has been very considerably enlarged, re-written to a great extent, and brought up to date by Mr. Smythies when home on leave from Borneo, where he is now stationed. The climate and topography of Burma vary a great deal, and in the coastal region tho annual rainfall is as much as 250 in., while in the dry zone-which eovers much of the centre of the country--it may not be higher than $50 \mathrm{in.}$. The author divides Burma into ten distribution areas, which are more-or-less the same as the civil divisions as shown on a map. As regards vertical zones of distribution, he defines the plains as from sea-level to $3,000 \mathrm{ft}$., the higher hills from the last. elevation to $6,000 \mathrm{ft}$. and finally the mountains which in some cases go well above $7,000 \mathrm{ft}$., the highest peak being Los Long $(8,771 \mathrm{ft}$.) in the Shan States. The vegetation naturally varies according to the rainfall and elevation, and all this is clearly and concisely described in the introduction.

Owing to the geographical position of the country, the birds are of exceptional interest. In the northwest there are species from the Indian region, in the cast there is a Sino-Himalayan element above $5,000 \mathrm{ft}$., and farther south there is a meeting with Indo-Chinese avifauna, while in the Tenasserim peninsula many Malaysian species are found. But taking the country as a whole, the fauna is made up of Assamese birds plus indigenous species; although many species from the adjoining regions penetrate far into the interior, on the whole the avifauna. seems so far to have been little affected with the development of the country. It is true that the Burmese, or green, peafowl and some of the silver pheasants have decreased, from shooting and trapping, in the more populous parts of the country. The draining and clearing of a large dismal swamp area in southern Burma to grow rice have banished tho spotted-billed pelicans and adjutants which used to brced there in great numbers, and now it is not known whether they nest anywhere in Burma. Writing of the adjutant in the early eighties, Oates described how each October they visited Pegu in great armies, and on first arrival could be seen all over the flat. country in groups of fifty close together. In February and March they departed. But these great number's are a thing of the past, as Mr. Smythies tells us, and though the bird appears to be widespread it is not common in most districts.

There is a short description given of each bird which, together with the plates, should be sufficient to name most of them. There are paragraphs on habits, food, nest and eggs, status and distribution. At the end of the book there is a systematic list with parallel columns showing the distribution of each species in the ten different areas. The thirty coloured plates, with a number of species on each, are a great asset to the book, and Commander Hughes is to be congratulated.

At the present time Burma is closed to ornithologists-which is unfortunate, since so much remains to be done. However, what we do know about Burmese birds has been ably brought together by Mr. Smythies, and the present edition is a great improvement on the first. N. B. KINNEAR 